\title{
A circulação da experiência da dor em narrativas no Facebook
}

Marlon Santa Maria Dias ${ }^{1}$ Viviane Borelli²

Resumo: Este trabalho reflete alguns aspectos da problemática da circulação na ambiência da midiatização. A partir de material coletado em um grupo de discussão no Facebook sobre a mobilização "Eu não mereço ser estuprada", analisamos as estratégias discursivas que compõem os processos de enunciação da mobilização dos atores sociais. Apontamos a reconfiguração narrativa na circulação da experiência da dor e a criação de redes interativas de apoio e aconselhamento.

Palavras-chave: midiatização; circulação; narrativa; experiência.

\section{La circulación de la experiencia del dolor en las narrativas en Facebook}

Resumen: Este trabajo refleja algunos aspectos de los problemas de circulación en el ambiente de la mediatización. A partir de material recogido en un grupo de discusión en Facebook sobre la movilización "No merezco ser violada", analizamos las estrategias discursivas que componen los procesos de enunciación de la movilización de los actores sociales. Señalamos la reconfiguración narrativa en la circulación de la experiencia del dolor y la creación de redes interactivas de apoyo y asesoramiento.

Palabras clave: mediatización; circulación; narrativa; experiencia.

\section{The circulation of the experience of pain in narratives on Facebook}

\begin{abstract}
This paper reflects some aspects of circulation problems in the ambience of mediatization. From material collected in a discussion group on Facebook about the mobilization "I don't deserve to be raped", we analyze the discursive strategies that produce the enunciation processes of social actors mobilization. We point out the narrative reconfiguration in the circulation of the experience of pain and the creation of interactive networks of support and advice.
\end{abstract}

Keywords: mediatization; circulation; narrative; experience.

${ }^{1}$ Mestre em Comunicação pelo Programa de Pós-graduação em Comunicação da Universidade Federal de Santa Maria. Bacharel em Comunicação Social, habilitação Jornalismo, também pela UFSM.

2 Professora do Programa de Pós-Graduação em Comunicação e do Departamento de Ciências da Comunicação da Universidade Federal de Santa Maria (UFSM), RS. Doutora em Ciências da Comunicação pela Unisinos. 


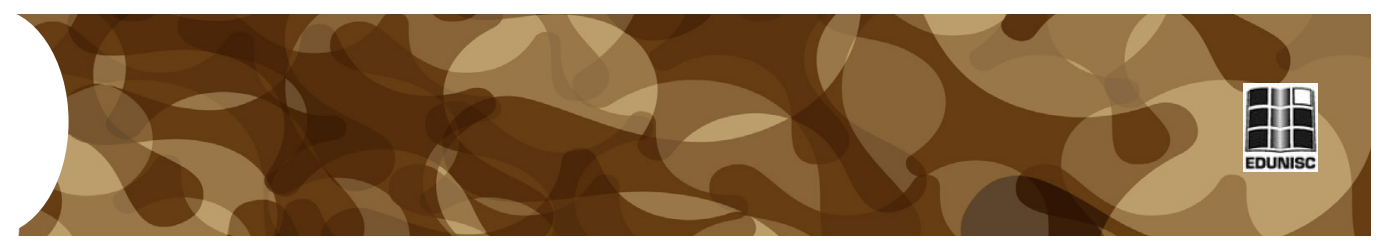

\section{Introdução}

Em 28 de março de 2014, a jornalista Nana Queiroz publicou em seu perfil no Facebook uma fotografia tirada em frente ao Congresso Nacional, em Brasília, na qual aparece seminua, da cintura para cima, cobrindo os seios com os braços, onde lemos a seguinte inscrição: "não mereço ser estuprada". A imagem que circulou nas redes sociais digitais, nos sites de notícia, blogs e nos veículos de mídia tradicional era um protesto em resposta a uma pesquisa divulgada no dia anterior pelo Instituto de Pesquisa Econômica Aplicada (Ipea), cujos dados apontavam a concordância da maioria dos respondentes à afirmação: "mulheres que usam roupas que mostram o corpo merecem ser atacadas" ". O protesto desencadeou a mobilização digital "Eu não mereço ser estuprada". A produção discursiva de atores, campos e mídias acerca dessa mobilização foi nosso objeto empírico de investigação ${ }^{4}$ e, agora, apresentamos alguns resultados a partir de um recorte com foco em uma problemática da recepção examinada por um outro lugar, o da circulação.

Partimos de uma discussão sobre a midiatização da sociedade, compreendendo-a como um fenômeno social, mas também enquanto os próprios mecanismos que a fazem funcionar, engendrando complexidades resultantes da instalação de novos modos de interação social (SODRÉ, 2002) e da transformação cada vez mais frequente de tecnologias em meios (FAUSTO NETO, 2008). Essas complexidades que envolvem processos midiáticos e sociais se desenvolvem em uma nova ambiência (midiatizada), que estrutura e organiza os sentidos e que se reconfigura a partir de operações midiáticas e de novas práticas de interação dos atores. Nesse cenário, desponta a problemática da circulação, que deixa de ser um lugar de passagem, em que os discursos transcorriam numa lógica linear, para se transformar no locus de um outro tipo de trabalho enunciativo dos atores (FAUSTO NETO, 2012).

Essa nova atividade de circulação acentua a descontinuidade entre as lógicas de produção e de recepção, num processo de acoplamentos que, longe de apontar para uma convergência de sentidos, se realiza segundo postulados de divergência (FAUSTO NETO, 2015). Nesse sentido, o "Eu não mereço ser estuprada" se constitui por meio de discursos construídos através de um trabalho enunciativo próprio de diferentes sistemas, mas que se encontram e sofrem injunções desse atravessamento decorrente da atividade circulatória.

Por meio de uma observação encoberta não participativa (JOHNSON, 2010), coletamos postagens dos atores membros de um grupo de discussão do Facebook nomeado "Eu não mereço ser estuprad@ [OFICIAL]", ambiente criado em decorrência da mobilização emergente. Elegemos o primeiro mês de observação do grupo para fazer o recorte e separar as postagens analisadas, que compõem o corpus analítico deste trabalho. Com o aporte teórico-metodológico da Semiologia dos Discursos Sociais (VERÓN, 2005; PERUZZOLO, 2004), analisamos as estratégias discursivas que compõem os
${ }^{3}$ Uma semana depois $(04 / 04 / 2014)$, o Ipea lançou uma nota oficial corrigindo os dados divulgados anteriormente. Segundo a nota, houve um erro na elaboração dos gráficos e a percentagem estava trocada: $26 \%$ (e não $65 \%$ ) dos entrevistados concordavam com a afirmação de que as mulheres que usam roupas curtas merecem ser atacadas. Disponível em: http://goo.gl/1UP8IL. Acesso: 23 jun. 2016

${ }^{4}$ Este artigo deriva da dissertação de mestrado "A circulação de sentidos em Eu não mereço ser estuprada: uma leitura do acontecimento midiatizado", defendida em março de 2016 no Programa de Pós-graduação em Comunicação da Universidade Federal de Santa

Maria, com financiamento da Capes. Uma versão prévia deste artigo foi apresentada na III Jornada Gaúcha de Pesquisadores da Recepção, em São Leopoldo, RS. 

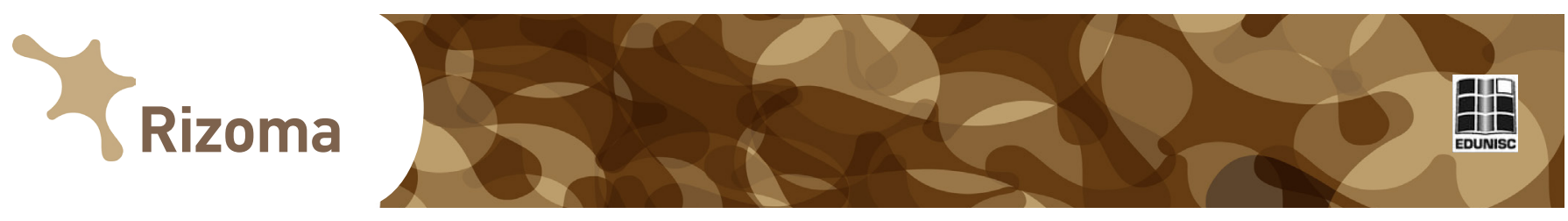

processos de enunciação da mobilização e apontamos, especialmente, para a criação de redes interativas de aconselhamento e de trocas de experiência sobre as violências sofridas.

Nosso esforço se concentra em compreender este receptor enquanto um "corpo-significante" (FAUSTO NETO, 2015), instância de produção e circulação de signos, que exterioriza signos de um trabalho enunciativo da dor. A partir da análise da interação discursiva, percebemos as relações entre aquilo que é vivido e o que é narrado pelas vítimas de abusos (DAS, 2007), as potencialidades dessas narrativas enquanto expurgação da dor e os arranjos dos atores interconectados em torno não só da resistência e do combate às opressões da sociedade machista, mas também na formação de redes de ajuda e luta.

\section{A circulação na sociedade midiatizada}

Ao acessarmos nossas contas em sites de redes sociais, deparamo-nos com uma infinidade de materiais advindos de polos de produção diversos. Uma explosão de fragmentos narrativos que trafegam em um ambiente de circulação complexo: de notícias e reportagens vinculadas aos conglomerados midiáticos tradicionais até material textual e audiovisual produzido pelos atores sociais, que versam sobre os mais diversos temas - da discussão política do momento a um relato íntimo sobre alguma situação vivida.

Compreendemos que este complexo cenário tem relação com a intensificação do processo de midiatização da sociedade. Esse processo refere-se às crescentes e progressivas afetações de lógicas de uma cultura midiática no ordenamento discursivo dos campos sociais, reconfigurando determinadas práticas. $\mathrm{O}$ conceito de midiatização é trabalhado em diferentes perspectivas nas pesquisas no campo da comunicação. Neste trabalho, fazemos uma leitura do fenômeno por um viés semiológico.

Na década de 1990, Verón (1997) publica um texto em que apresenta um esquema para a análise da semiose da midiatização. O esquema é composto por três círculos: o primeiro deles representa as instituições; o segundo, as mídias; e o terceiro, os atores individuais. Esses círculos estão todos postos em relação por duplas flechas, ou seja, afetações recíprocas entre instituições, mídias e atores. O esquema, que embasou estudos posteriores, mostra a tentativa de Verón de analisar por um olhar relacional a complexidade do fenômeno da midiatização e dos múltiplos aspectos de mudança social nas sociedades industriais.

É a partir da leitura de Verón (1997) que Sodré (2002) propõe pensarmos na existência do que ele chamou de bios midiático, que se refere a uma nova ambiência em que os modos de vida são alterados e se passa a viver a realidade da mídia, dentro de uma cultura própria, a tecnocultura, em que os sujeitos entram em relação por meio de interações também peculiares, as tecnointerações. Para o autor, o processo de midiatização se refere à "articulação hibridizante das múltiplas instituições [...] com as várias 

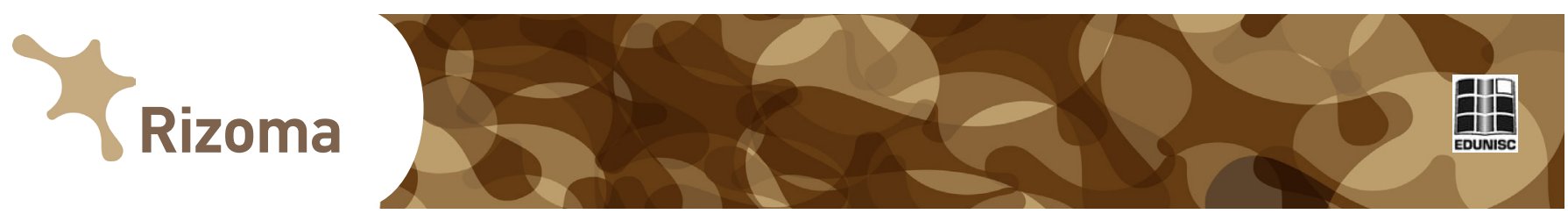

organizações de mídia" (SODRÉ, 2002, p. 24) com atividades regidas por um código semiótico específico.

A ideia de uma ambiência midiatizada aponta para a reconfiguração das práticas e do modo como as pessoas entram em relação, ou seja, interagem entre si. Nesse sentido, Braga (2007) propõe pensarmos a midiatização como um processo interacional de referência ainda incompleto. Para o autor, as relações sociais passam, cada vez mais, a serem orientadas por lógicas da mídia. Quando fala "de referência", Braga sinaliza determinados processos definidores de lógicas que orientam os demais processos. A escrita tem sido o processo interacional, já foi a oralidade. Um processo não anula ou exclui o outro, mas se ajustam na sociedade midiatizada.

Verón (2014) entende que o fenômeno da midiatização se relaciona aos processos de semiose social, entendendo-o como a exteriorização dos processos cognitivos na forma de dispositivos materiais. Por esse viés semioantropológico, os fenômenos midiáticos seriam uma característica universal de todas as sociedades humanas. Segundo o autor, as grandes transformações que aconteceram no decorrer da história da humanidade trariam a marca da adoção de um dispositivo técnico-comunicacional pelas comunidades. Assim, o ponto inicial da midiatização, para Verón, situa-se na indústria da pedra, no período neolítico, com a exteriorização de processos mentais na materialidade dos utensílios.

Essas diferentes (e, por vezes, complementares) formas de entender a midiatização - enquanto processo, ambiência, fenômeno etc. - apontam para uma processualidade histórica no entendimento do conceito, enquanto marca de uma racionalidade que se intensifica nos dias atuais, em um contexto de sociedades (pós-) industriais. Nesse sentido, Fausto Neto (2008) distingue o que ele entende por "sociedade dos meios" e "sociedade midiatizada": na primeira, a mídia ocupa um lugar central, de mediação das simbólicas sociais entre os campos e os atores, enquanto na segunda a mídia já organiza discursivamente o funcionamento de outros campos sociais, com suas lógicas afetando a sociedade, os sujeitos e suas práticas. Estaríamos, de acordo com o autor, vivenciando essa passagem.

Para Fausto Neto (2006, p. 3), a sociedade midiatizada faz funcionar "um novo tipo de real, cuja base das interações sociais não mais se tecem e se estabelecem através de laços sociais, mas de ligações sociotécnicas". Sua visão contraria as teorias que preconizavam uma unificação do consumo a partir da convergência tecnológica. Para o autor, a midiatização aponta para outro caminho, bastante complexo e incompleto, de descontinuidades e segmentação, uma nova forma de sociedade fragmentada e heterogênea. Desse modo, o autor percebe que há um processo de afetação que é estimulado pela midiatização, em que esta causa reconfigurações tanto nas práticas sociais dos atores sociais coletivos ou individuais quanto no próprio campo das mídias, através dos meios tradicionais de comunicação.

A partir desse breve embasamento sobre midiatização, apontamos uma problemática que desponta ao pensarmos as reconfigurações advindas de tal 

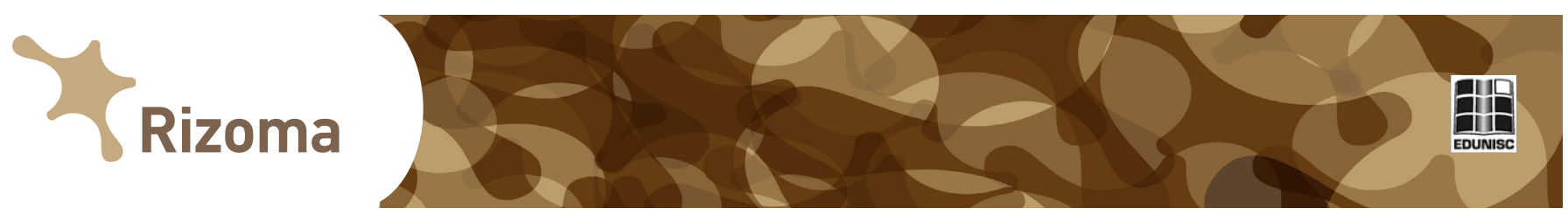

fenômeno: a ruptura da preponderância do polo de emissão, a proliferação de produções midiáticas daqueles que, tradicionalmente, ocupavam o lugar da recepção e as disjunções entre produção e recepção direcionam nosso olhar para as zonas de circulação, por onde trafegam esses sentidos.

Os estudos pioneiros do campo apresentavam modelos funcionalistas que buscavam elucidar os processos de comunicação. Essa visão transmissional, mesmo que superada pelos estudos posteriores, vigora ainda que implicitamente na forma como se observam tais fenômenos. Por muito tempo, produção e recepção foram vistas como polos estanques. Com a complexificação dos processos sociocomunicacionais, urge a necessidade de atentarmos para os deslocamentos dessas instâncias, assim como para as articulações observáveis na zona de circulação. Braga (2012, p. 39) salienta que, mais do que pensar na relação produtor/receptor, interessa refletir que a circulação ultrapassa a situação da recepção, afinal, o receptor "faz seguir adiante as reações ao que recebe".

A circulação deixa de ser um lugar de passagem, em que os discursos transcorriam numa lógica linear, para "se transformar num espaço de interfaces, segundo outro tipo de trabalho enunciativo, de natureza assimétrica cujas marcas de suas manifestações, geradas por produtores e receptores, se tornariam empiricamente mais visíveis" (FAUSTO NETO, 2012, p. 46). Não mais sob a égide das instituições, a centralidade das referências de inteligibilidade se desloca e as interações são dinamizadas por processualidades de ordem tecnodiscursiva. Assim, campos/instituições, mídias e atores produzem mensagens que seguem singulares processos discursivos e que tomam novas formas quando se embatem e são afetados pela complexidade do trabalho de circulação (FAUSTO NETO, 2015).

$\mathrm{O} E u$ não mereço ser estuprada, enquanto mobilização e acontecimento, é constituído por enunciações diversas e pulverizadas, a partir de um trabalho de circulação que põe em relação as instituições, como o Ipea, que realizou a pesquisa, a mídia e os atores que integram o protesto. Se antes havia a dificuldade de fazer com que a produção discursiva dos atores sociais alcançasse um número considerável e disperso de pessoas, hoje esse cenário se modificou. É pensando nesses relatos das "pessoas comuns", dessas "vidas ordinárias", para lembrar Certeau (1998), que focamos essa reflexão nas narrativas que emergem nos ambientes digitais sobre a experiência de violências contra mulheres. Nosso olhar se direciona ao cotidiano (CERTEAU, 1998; DAS, 2007) que emerge nas falas dessas mulheres que buscam compartilhar a radical singularidade da dor por meio de suas postagens.

\section{A experiência da dor}

Situações de violências são marcas da vida de muitas pessoas. Neste trabalho, especificamente, pensamos a violência contra as mulheres, que se manifesta de modos diversos e tem como uma de suas práticas mais 

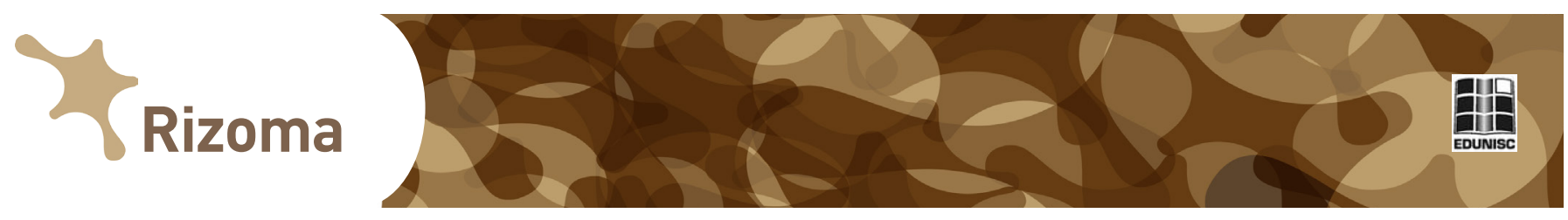

devastadoras o estupro. Eu não mereço ser estuprada nasce da coesão das vozes de mulheres indignadas, que vivem sob essa frequente ameaça. Podemos considerar, neste contexto, o estupro enquanto este evento crítico (DAS, 1996) que modifica profundamente a vida dessas mulheres, que têm suas biografias amarradas em torno da temática da violência (DAS, 2007) e cujas marcas as acompanham cotidianamente. São marcas de sofrimento que precisam de expurgação, mas esta não se resolve de modo repentino.

As violências a que as mulheres estiveram historicamente submetidas encontraram pouco espaço de reverberação e indignação ao longo dos séculos. As sociedades patriarcais, heteronormativas e machistas por muito tempo interditaram esses discursos, naturalizando a violência e impondo à mulher a culpa pelos abusos - por seu comportamento, sua vestimenta, seus hábitos. Esse cenário vem se modificando, cada vez mais, por meio da luta de movimentos feministas, cujas articulações se reconfiguram hoje em decorrência do contexto das tecnologias digitais.

Se outrora essas mulheres só podiam guardar para si essa dor e construir em cima dela novas formas de habitar o mundo, como salienta Das (2007), hoje há novos meios de se vivenciar e narrar esse sofrimento. Uma mobilização anti-estupro como Eu não mereço ser estuprada nos mostra outros modos de organização e articulação dos atores sociais em torno de uma temática sensível: esses atores não só encontram formas de protestar, mas também de desconstruir ideias conservadoras e ainda perpetuadas por instituições e, claro, pelo próprio discurso midiático hegemônico. Em meio a esses embates, cujas lógicas se guiam por funcionamentos próprios da midiatização, identificamos a presença forte de narrativas biográficas que se ancoram em relatos de sofrimento, que não são mais guardados para si, mas compartilhados e espraiados nas redes digitais.

Frente a esse cenário, em que as narrativas se complexificam e circulam seguindo rotas difusas, propomos a análise mais detida de um grupo de discussão criado no Facebook, intitulado Eu não mereço ser estuprad@[OFICIAL], afim de identificar estratégias discursivas que apontam para a formação de redes interativas de apoio, aconselhamento e encorajamento no enfrentamento dessa dor. Utilizamos o material coletado durante um mês de observação sistemática de caráter encoberto não participativo (JOHNSON, 2010) no grupo. Na sequência, apontamos quatro estratégias discursivas identificadas a partir da observação e análise dos enunciados que denotam as práticas interativas atravessadas pela experiência dos atores ao narrar a dor.

\section{Estratégia de aconselhamento}

Essa estratégia refere-se ao modo como determinados discursos se constroem a partir do acolhimento do outro, direcionando ações futuras e ressaltando que há aspectos positivos nesse outro sujeito. Em um grupo de 

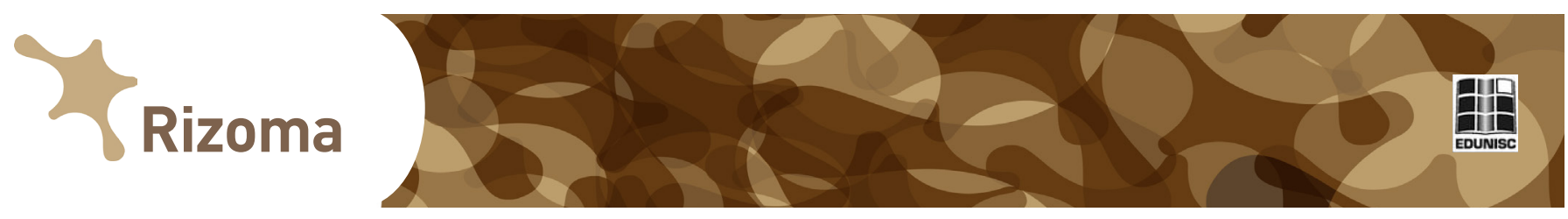

discussão que se reúne em torno de uma temática da ordem do sensível, há muitas pessoas que relatam suas histórias de sofrimento.

Estamos juntas para reafirmar que a culpa não é nossa, nos empoderar. Esse espaço aqui é nosso, de denúncia, de amor e de acolhimento. E esse processo de construção feminista está lindo, continuemos assim. Sororidade sempre. Amo todas vocês! (E01, 31/03/2014)

Não, meu bem, não tenha medo. Tenha força! Pra lutar a todo momento e poder ajudar a cada uma dessas meninas e também meninos que são violentados [...] [E02, 13/04/2014]

[...] Não assista a isso calad@. Denuncie, reaja, resista, lute! O mundo é o espelho das suas ações. Ou omissões. [E03, 01/04/2014]

$\mathrm{O}$ aconselhar refere-se a um movimento estratégico de construir um discurso que mostre, antes de tudo, que a mulher é vítima do abuso e que ela não deve se culpar por isso. Nessa estratégia discursiva, encontramos marcas de uma interlocução que insere o enunciador no mesmo grupo do destinatário, aproximando um do outro. Uma dessas marcas é a utilização do verbo na primeira pessoa do plural ("estamos", "nossa/o", "nos", "continuemos"). Outra marca discursiva é a utilização da segunda pessoa, denotando a inserção do enunciatário no enunciado ("amo todas vocês!"). Em E02, percebemos o uso do vocativo "meu bem" para se referir ao enunciatário, um modo carinhoso de tratamento. Essas marcas, como afirma Peruzzolo (2004), constroem um efeito de aproximação que caracteriza a própria subjetividade. A utilização de exclamações direciona o leitor, marcando a interlocução.

Outra característica da estratégia de aconselhamento é a utilização de verbos no imperativo ("tenha força", "Denuncie, reaja, resista, lute!"), que marcam a necessidade de uma reação por parte da vítima em denunciar a agressão ou situações de abuso. A estratégia de aconselhamento está relacionada com a estratégia apresentada na sequência, o reconhecimento da potência de si, afinal, a intenção do conselho é fazer também com que a mulher encontre em si as potencialidades para viver plenamente.

\section{Estratégia de reconhecimento da potência de si}

Identificamos essa estratégia discursiva a partir da análise de enunciados que trazem a ideia de que a mulher pode ser o que quiser, reforçando a necessidade de coragem para resistir e combater opressões cotidianas. Em E04, podemos perceber essa estratégia em operação. O reconhecimento da potência é instigado aqui através de uma história de vida real, que por meio de sua enunciação busca convencer o outro de que é possível encontrar a força necessária para resistir dentro de si.
${ }^{5}$ Mantemos o anonimato das pessoas do grupo e identificamos os enunciados apenas por um número. Os grifos neste e nos demais enunciados são todos nossos. 


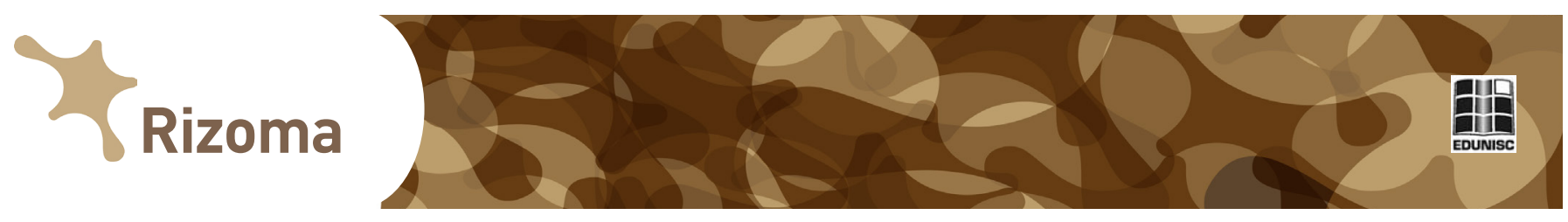

Ontem, a caminho da faculdade fui assediada por um homem que falou obscenidades para mim no meio da rua e das pessoas como se fosse algo normal (infelizmente para ele era). [...] eu lembrei de todos os relatos e toda a revolta de vocês, mulheres corajosas que vemos todos os dias aqui, isso me deu uma força que eu nunca imaginei que eu poderia ter de fazer um escândalo onde eu estava e mostrar para todo mundo que "cantada" é assédio. (E04, 01/04/2014)

J., parabéns! É uma raiva imensa que a gente sente. Às vezes dá pra revidar, às vezes não dá (se a cantada vem, por exemplo, de um chefe ou de um cliente. Mas saber que a culpa não é sua é incrivel. Queria que nenhuma mulher se sentisse culpada por esse tipo de situação. (E05, 01/04/2014)

O enunciador de E04 constrói o seu relato utilizando determinadas marcas que criam efeitos de real do ocorrido, como marcas de tempo, espaço e situação ("ontem", "a caminho da faculdade", "no meio da rua e das pessoas", "eu estava"). Há também a inserção do enunciatário no discurso, com o uso recorrente do "vocês", adjetivando o enunciatário, caracterizando-o como "mulheres corajosas". Essa marca de interlocução aponta para quem especificamente este enunciado se dirige: outras mulheres que possam se sentir encorajadas a também se manifestarem discursivamente para resistir ao machismo.

Em E05, temos uma das respostas ao E04, que enuncia uma satisfação em saber que a vítima não se culpabiliza pelo assédio e um desejo de que esse sentimento de potência seja mais recorrente entre as mulheres. E05 se coloca também no lugar de quem sofre com situação semelhante e que também teria uma história real para contar em relação a isso. Nessa estratégia discursiva de incluir-se no discurso do outro, vemos com recorrência o relato de histórias de vida, que estabelecem uma relação de proximidade com o enunciatário e buscam persuadi-lo da veracidade do que é dito a partir de um fato que ocorreu efetivamente. Os enunciados destacados reforçam esse sentido de apoio e solidariedade entre as mulheres.

Como o grupo funciona como um espaço de compartilhamento de relatos e também de informações relacionadas à violência contra a mulher, encontramos discursos que trazem a marca da resistência e que se impõem como vozes que clamam por uma mudança. É o que percebemos em marcas do E06, quando o enunciador se coloca em relação de proximidade com o enunciatário, a partir da utilização da primeira pessoa do singular, e indica ações que devem ser feitas para que as mulheres se reconheçam livres e possam exercer essa liberdade sem mais se guiarem pelos "ensinamentos dessa cultura patriarcal, sexista e machista".

Somos maioria no país. Não podemos nos permitir ser manipuladas $e$ dominadas pela minoria. Nem sou a favor da superioridade nem da inferioridade feminina. Sou a favor da igualdade de direitos. Que sejamos livres para nos expressarmos e agirmos da forma que nos convém e não de acordo com os ensinamentos dessa cultura patriarcal, sexista e machista. Ser mulher não me torna inferior, culpada. \#orgulhodesermulher \#guerreira \#independente \#livre (E06, 31/03/2014)

$\mathrm{N}$ : Eu ouvi barbaridades vindas de mulheres, meninos, homens, mais eu já disse, não ficarei calada, não vou deixar minhas amigas|mães|filhas sofrerem, 


\section{Tizoma}

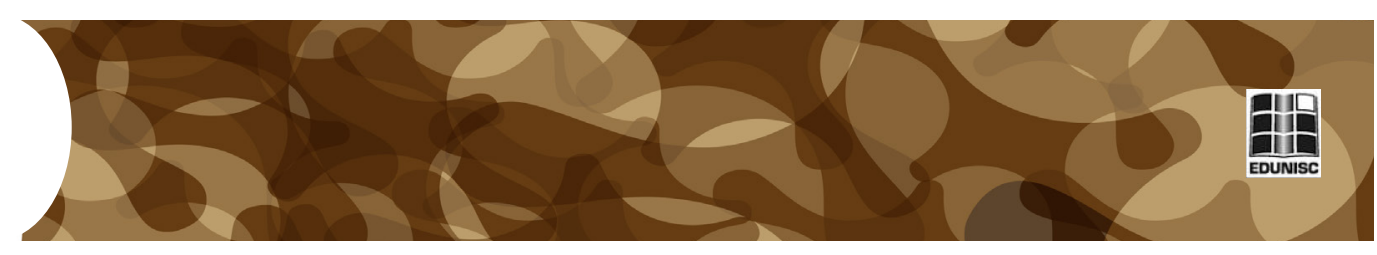

Bandeira erguida!!!

A. Você não está sozinha, N.! Isso só acontece porque sempre ficamos caladas!!! Agora gritamos!!!

N. Sabe a minha felicidade? Diretor, professores, funcionarios, estão lutando junto comigo na escola!

A. E nós também! Mesmo de longe [E07, 01/04/2014]

No E07, por sua vez, percebemos a interação entre dois enunciadores, identificadas aqui como N. e A. O diálogo se refere à comemoração de $\mathrm{N}$. por conseguir espaços em sua escola para falar sobre feminismo e violência de gênero. A. dirige sua fala diretamente à N., chamando-a pelo nome e usando o pronome "você", o que marca as pessoas presente no discurso. Ao afirmar "agora gritamos", A. reforça o sentido de que N. "não está sozinha", pois denota a construção discursiva de mais de um enunciador (um eu e um tu), em que as pessoas daquele ambiente de interação constituem um coletivo que, mesmo distantes geograficamente, se unem em torno de um objetivo comum, caracterizando tal arranjo social como uma mobilização emergente que visa à conquista de direitos de equidade social. O advérbio "agora" remete a algo que antes não ocorria, ou seja, a enunciadora avalia que no momento presente pode expressar-se de forma distinta. Do mesmo modo, o "agora" também pode remeter ao fato de que nas redes sociais digitais há um espaço que possibilita expressões desse tipo e que é construído constantemente com a produção discursiva dos atores interconectados.

\section{Estratégia de expurgação da dor}

A estratégia de expurgação da dor é identificada em enunciados cuja intencionalidade aponta para a necessidade de transformar em discurso uma experiência sofrida. É frequente, no grupo, a ideia de que é necessário falar sobre o que se vivenciou de ruim para se livrar da dor. Assim, os enunciados postados possuem marcas discursivas que remetem a uma função de cura e de abrandamento da dor.

Fui abusada ainda jovem, dentro da família. [...] Conto essa história porque não aguento guardar pra mim uma dor que é gigante. Por muito tempo me senti culpada e não falei pra ninguém. Até por vergonha do q aconteceu. Hoje não... conto pra não viver mais com isso. [...] espero q voces também contem, escrevam, mas não guardem mais essa dor (E08, 02/04/2014)

Alguns anos atrás sofri um abuso, e ouvi: 'tb vc procurou!', detalhe: estava de calça, blusa fechada, tênis, cabelos presos... O argumento usado: "Foi no lugar errado, na errada"... Doeu, virei estatística! Mas, sinceramente superei, hj sou ativista declarada, sabem pq? Combato de uma forma ou de outra esse tipo de prática todas os dias [...] (E09, 15/04/2014)

Eu peguei um ônibus quando tinha 16 anos [...] Um homem estrou e ficou em pé a meu lado. O espaço era muito pequeno, minusculo. [...] De repente senti que os dedos dele estavam abrindo meu ziper da calça, porque por conta do aperto ele posicionou a mao de tal forma que ficasse perto da minha vagina. 


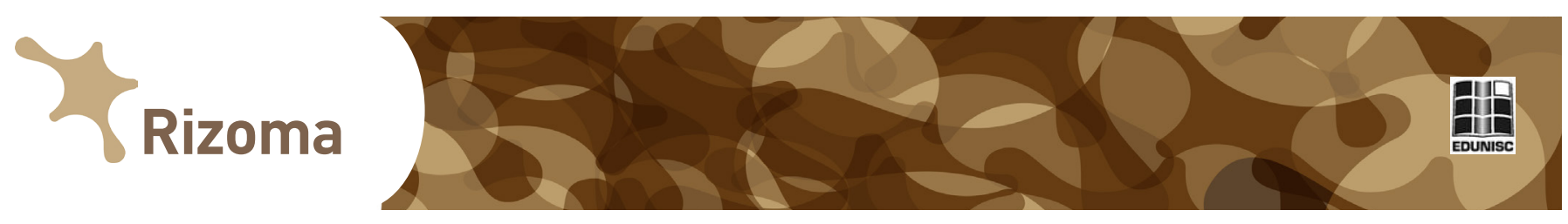

Eu achei que era só um problema de posicionamento MEU, me mexi um pouco e me afastei. Ele continuou. [...] Ele me olhou nos olhos e me intimidou demais. [...] Eu NUNCA contei isso a ninguem, [...] até esse momento. sao 11 anos desde que aconteceu. Sabe como é alguém dizer que tanto faz a sua dor, que você nao entende do assunto, que você não sabe o que ta dizendo. EU SEI o que to dizendo. Eu espero que a causa continue, que de certo... [E10, $22 / 04 / 2014]$

Nos três relatos percebemos que os enunciados são construídos na primeira pessoa, por se tratar de uma experiência pessoal e dita a partir do lugar singular de quem a vivenciou. Há marcas, assim, da presença desse enunciador no discurso, que depois interpela o interlocutor ("espero q voces", "sabem pq?", "Sabe como é alguém dizer que tanto faz a sua dor [...]") declarando anseios em relação às ações dos destinatários ou questionando e impondo a esse enunciatário a função de colocar-se em seu lugar (por meio de questionamentos e a referência a 'vocês'), criar empatia, procurar colocar-se no lugar do outro, mesmo que a experiência da dor seja singular.

É notável nos enunciados o objetivo de mostrar que a libertação da dor é um trabalho coletivo e que, dentro do grupo, isso é possível de ser realizado através de discursos que remetem a trocas de experiência. As dinâmicas interacionais do grupo permitem que as histórias sejam publicadas e que, ali mesmo, se crie uma rede discursiva que remete à estratégia de aconselhamento e reconhecimento do potencial de si, enquanto respostas aos relatos de abuso, como percebemos em E11.

[...] que relato maravilhoso! Nossa! Enquanto eu lia o teu texto, vieram várias situações que eu passei (e que como você mesma disse, infelizmente, é normal). Parabéns pela força, pela garra, e principalmente pela atitude!!!!! E com toda certeza: MACHISTAS NÃO PASSARÃO!!!! [E11, 01/04/2014]

A estratégia discursiva de expurgação da dor se constrói enquanto um relato narrativo, que busca contar uma história, sendo construída com elementos próprios da narrativa: verbos de ação, localização espaçotemporal, descrições dos ambientes, personagens e conflito. Implicitamente, os enunciadores dos relatos de abuso convocam o interlocutor a falar. A resposta esperada não é, diretamente, uma mensagem de conforto, mas sim um outro relato, até que não se tenha mais o que relatar, que não se tenha mais por que sofrer. Como Castells (2013) aponta, indignação e esperança é o que une essas mulheres em torno do protesto. A esperança, por fim, se resume a crer que crimes como os abusos cometidos contra elas não voltarão a acontecer e, se acontecerem, terão punições.

Assim, o trabalho enunciativo de relatar os abusos sofridos se insere numa cadeia discursiva que tensiona a autoralidade da mobilização Eu não mereço ser estuprada. Ou seja, a centralidade do acontecimento não se detém em Nana Queiroz, jornalista que iniciou o protesto com a publicação de sua foto, afinal, outras pessoas se inserem no protesto e o apreende de diferentes modos. A autoralidade é movente e se dilui nos fluxos a partir do momento em que existe uma outra circulação (baseada na experiência) 

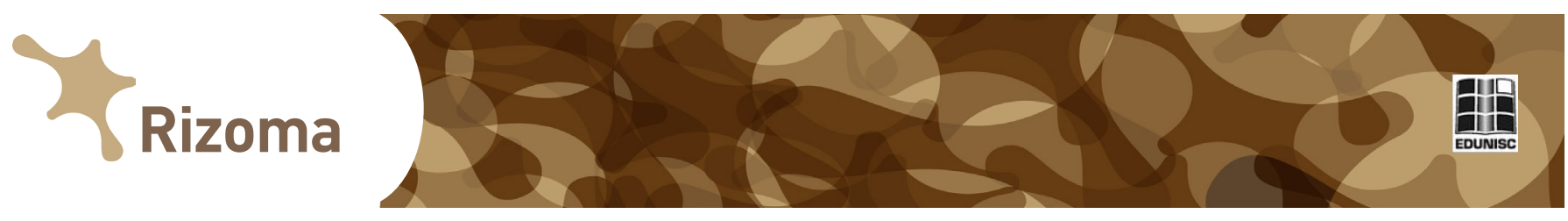

no grupo que faz com que Nana perca a autoralidade do acontecimento às dinâmicas sociais.

\title{
Estratégia de ajuda
}

A estratégia discursiva de ajuda refere-se a enunciados que apontam para a necessidade do outro na transformação de algo que diz respeito àquele que enuncia. É um clamor por auxílio, uma convocação do outro, para que este atente ao seu problema, atrelando este outro a algo que diz respeito à ordem do privado. De algum modo, assim, esses enunciados também questionam a própria função do grupo de discussão, trazendo para a pauta algo íntimo e inquerindo respostas.

\begin{abstract}
Meninxs, peço a ajuda de vocês para divulgar o caso de estupro que ocorreu com uma conhecida da minha vizinha. Peço para que mesmo não morando no Rio de Janeiro compartilhem para dar visibilidade ao caso que ocorreu na região de Jacarepaguá. [E12, 24/04/2014]
\end{abstract}

Vamos ajudar esse pai que precisa de nós nesse momento delicado. Por favor, alguém??? (E13, 30/04/2014)

Nos enunciados destacados acima, temos enunciadores que clamam pela ajuda dos demais na divulgação e resolução de casos de violência. Em E11, o enunciador sinaliza a sua relação com a vítima (vizinha) e faz uma referência de real ao apontar a localização geográfica do fato ("região de Jacarepaguá"). O enunciador deixa claro que sua intenção é tornar o caso visível, com anseios de que a visibilidade possa trazer alguma resolução. No mesmo sentido, E13 enuncia de um lugar em que fala enquanto integrante de um coletivo. Ao dizer que aquele pai "precisa de nós" (em referência a um pai que procura justiça para o caso de violência contra sua filha), o enunciador lança aos integrantes a responsabilidade pela ajuda e reforça os sentidos sobre a função do grupo enquanto coletivo: a ajuda daqueles que se integram à mobilização por se sentirem afetados pelo que estava acontecendo. $\mathrm{O}$ acontecimento se constrói, assim, a partir da união desses discursos e da atorização dos que são afetados por ele, como percebemos também em E14.

A esposa do meu primo teve que realizar o parto, e acabou por passar por momentos de tortura e dor, eu vim pedir uma ajuda de como reagir a casos de violência obstétrica. [...] vou chama-la de MÃE; MÃE passou por 19 horas de terror, MÃE ficou muitas horas numa maternidade numa cidade do interior do Ceará, [...] Forçando o parto, deitaram-na no chão, sentaram na barriga dela, puxaram a criança para fora, mas não conseguiram tira-la por inteiro e então a empurraram pra dentro de novo e só depois de tudo isso foi que a levaram para a mesa de cirurgia e fizeram um parto cesária. [...] MÃE se encontra traumatizada, sentiu muitas dores pós parto e com a barriga bastante inchada [...] não permitiram tirar fotos da criança nesses oito dias. Não sabemos o que fazer, como agir e como podemos processar, enfim, que atitude tomar, pedimos a ajuda de vocês, por favor! [E14, 17/04/2014] 

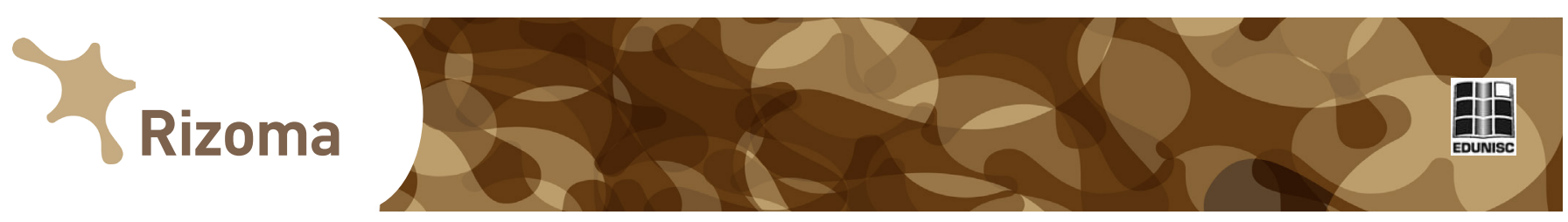

O enunciador de E14 narra os "momentos de tortura" pelos quais uma mulher ("a esposa do meu primo") passou durante o parto. O enunciador constrói um texto em que relata a cronologia da situação e utiliza o recurso de nomear a personagem de seu relato como "MÃE" para não comprometer sua identidade. Ao nomeá-la dessa forma, cria um vínculo de identificação e afetação com as demais mães do grupo. MÃE passa a ser protagonista da ação.

O homem recorre ao grupo para se informar como deve proceder para realizar a denúncia, o que denota que o enunciador construiu um sentido próprio para a finalidade do grupo que deveria se basear na ajuda mútua. $\mathrm{O}$ enunciador deixa claro que o texto é um pedido de ajuda e se utiliza de referências à realidade, como o lugar onde a situação ocorreu. Esse é recurso para atestar a veracidade do que está falando, especialmente porque o grupo é composto por pessoas de diversos lugares, sendo sua intenção convencer o interlocutor de aquilo que está sendo dito é verdadeiro. O relato quebra com o habitual do grupo no que se refere a relatos da ordem do íntimo, visto que não é uma mulher contando sua história, mas um homem relatando o abuso de um familiar e a aparente inoperância e irresponsabilidade das autoridades. As respostas dos outros atores direcionam para diversas atitudes:

Denuncie no conselho de medicina regional. No site [...] do Conselho Federal de Medicina tem tudo explicado, vcs tem que ir na regional do local onde aconteceu. Coloquem o nome dos médicos. Detalhem tudo. (E acredito que vcs podem tirar fotos do seu filho sim). [...] Melhoras para todos da família. [E15, 17/04/2014]

Mt triste,existem milhares de mulheres que passam por isso,e ninguém faz nada, que tal isso q aconteceu alcançar a mídia tbm?,tente denúnciar em algum programa de televisão tbm, isso deve mudar,boa sorte a você e parabéns pela sua atitude! [E16, 17/04/2014]

Em E15 e E16, vemos os enunciadores indicando maneiras para solucionar o caso apresentado em E14. Os verbos no imperativo presentes em E15 apontam uma ordem, um direcionamento daquilo que as pessoas envolvidas no caso da violência obstétrica devem fazer. Percebemos que a denúncia é o caminho apontados por ambos: em E15, vemos o enunciador enumerar o que deve ser feito para, em nível administrativo, punir os culpados; enquanto E16 sugere que o caso chegue até algum programa de televisão. Aqui percebemos que existe o efeito de reafirmar a credibilidade e a importância da instância midiática tradicional (televisão) no confronto das opressões. Há um valor de visibilidade implícito no enunciado, que tensiona as relações existentes entre a produção discursiva dos atores e aquilo que pode ser produzido discursivamente pela mídia hegemônica.

As interações discursivas proporcionadas pelo modo de organização do grupo e que são prescrições do próprio funcionamento do sistema midiático ocorrem de forma a alimentar uma cadeia discursiva diversa e ampla que se constitui a partir da ação dos sujeitos 

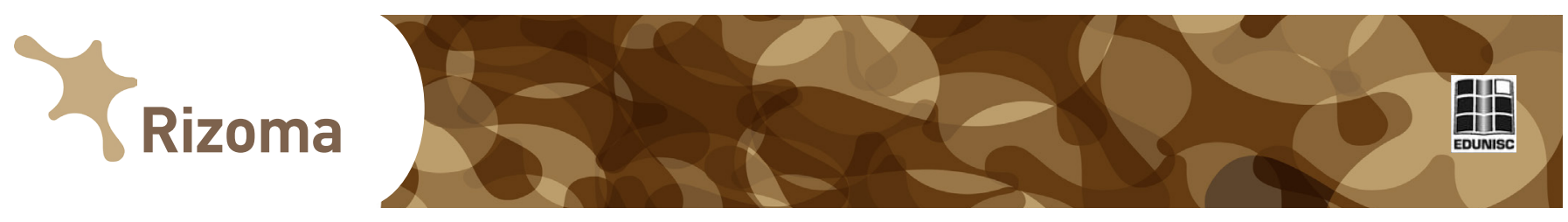

que ali se inserem. Com finalidades distintas, os enunciadores visam construir algumas relações com os outros: contar alguma experiência, compartilhar dúvidas e expectativas ou ainda para pedir orientações sobre como solucionar problemas.

\section{Considerações Finais}

Partimos de um acontecimento específico, a mobilização Eu não mereço ser estuprada, para entender as possibilidades interativas das redes sociais digitais e observar embates discursivos e articulações dos coletivos de atores sociais em torno da temática do estupro. $\mathrm{O}$ acontecimento já se constrói sob lógicas e injunções da sociedade da midiatização, em um complexo trabalho de circulação que mobiliza diferentes sistemas - científico, institucional, midiático, dos atores sociais etc. A mobilização se constitui pelas práticas dos atores e vai se construindo pela narração também da mídia tradicional, que apreende o acontecimento a partir de seus regramentos próprios. Neste trabalho, detemo-nos em relatos coletados num grupo de discussão, afim de compreender como a experiência da dor circula e constitui novos mundos por meio de sua narração.

Identificamos estratégias discursivas que buscam fortalecer o próprio movimento a partir da união e valorização do eu no e para o coletivo. Os fragmentos narrativos analisados se referem a discursos que se amparam na ideia de uma irmandade feminina (sororidade) necessária para o fortalecimento da luta e da própria manutenção da mobilização e do coletivo. Os sentidos de sororidade constroem a mobilização por meio de vínculos estabelecidos entre os atores, que enunciam suas histórias de vida e criam redes de aconselhamento. A narrativa de histórias de vida também produz marcas discursivas acerca de um modo singular de enunciar vivências. Além disso, cada ator elabora seus próprios sentidos acerca do que concebem ser a função do grupo (lugar para pedir aconselhamento, ajuda, tirar dúvidas e compartilhar experiências).

São estratégias que visam exteriorizar signos de um trabalho de dor e criar redes de auxílio para vítimas de violência de gênero. A análise das estratégias discursivas mostra como o acontecimento ganha novos sentidos a partir da produção discursiva dos atores, que agregam informações e funções ao grupo e inserem relatos biográficos que "dão corpo" ao que o enunciado Eu não mereço ser estuprada simboliza. Essas enunciações possuem rotas de circulação próprias que são impulsionadas pelo trabalho de circulação midiática, mas não mais reféns da lógica dos tradicionais meios de comunicação, ou seja, os atores enunciam e mesmo que não em dimensão comparável à mídia tradicional - conseguem mobilizar novos narrares e desestabilizar polos tradicionais de recepção e concentração da emissão. 


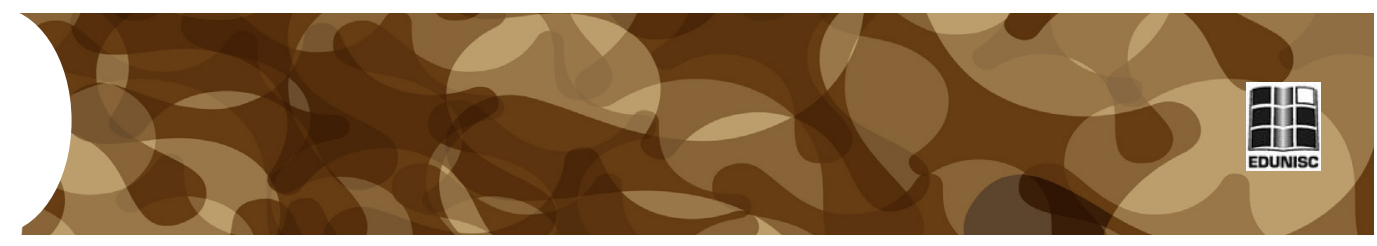

\section{Referências}

BRAGA, J. L. Mediatização como processo interacional de referência. In: MÉDOLA, A. S.; ARAUJO, D.; BRUNO, F. (org.). Imagem, Visibilidade e Cultura Mediática. Porto Alegre: Sulina, 2007, p. 141-167.

Circuitos versus Campos Sociais. In: MATTOS, M. A.; JANOTTI JUNIOR, J.; JACKS, N. (org.). Mediação e midiatização. Salvador: EDUFBA, 2012, p. 31-52.

CASTELLS, M. Redes de Indignação e esperança: Movimentos sociais na era da internet. Rio de Janeiro: Zahar, 2013.

CERTEAU, M. de. A invenção do cotidiano. Petrópolis: Vozes, 1998.

DAS, V. Critical events: an anthropological perspective on contemporary India. New Delhi: Oxford University Press, 1996.

Life and words: violence and the descent into the ordinary. California: University of California Press, 2007.

FAUSTO NETO, A. Midiatização, prática social: prática de sentido. In: Encontro Anual da Associação Nacional dos Programas de Pós-graduação e Comunicação (COMPÓS), 15, Bauru/SP. Anais... 2006.

Fragmentos de uma "analítica" da midiatização. Matrizes. São Paulo: ECA/USP, n. 1, 2008, p. 89-105. Disponível em: <http://www.usp.br/ matrizes/img/02/Dossie5_fau.pdf $>$. Acesso em: 20 jun. 2014.

Narratividades jornalísticas no ambiente da circulação. In: PICCININ, F.; SOSTER, D. (Org.). Narrativas comunicacionais complexificadas. Santa Cruz do Sul: EDUNISC, 2012.

. Recepção, 'corpo-significante' em circulação. In: BRIGNOL, L. D.; BORELLI, V. Pesquisa em recepção: relatos da Segunda Jornada Gaúcha. Santa Maria: FACOS-UFSM, 2015, p. 17-24.

JOHNSON, T. Pesquisa social mediada por computador: questões, metodologias e técnicas qualitativas. Rio de Janeiro: E-papers, 2010.

PERUZZOLO, A. C. Elementos de semiótica da comunicação: quando aprender é fazer. Bauru: EDUSC, 2004.

SODRÉ, M. Antropológica do espelho. Petrópolis: Vozes, 2002. 


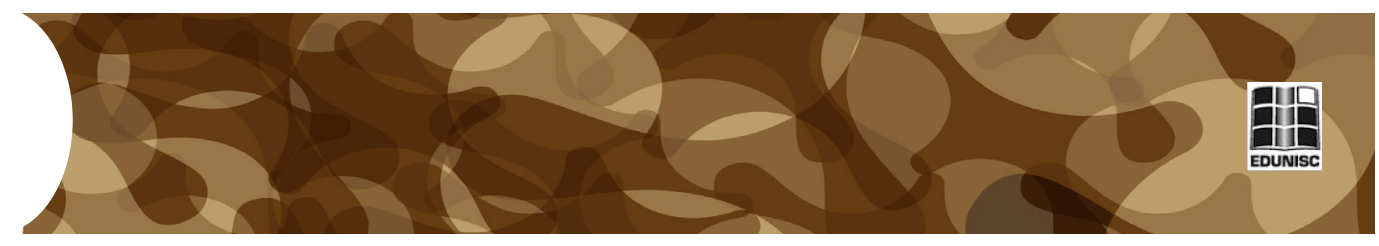

VERÓN, E. Esquema para el análisis de la mediatización. Revista Diálogos de la Comunicación, n. 48, Lima: Felafacs, 1997.

Fragmentos de um tecido. São Leopoldo: Unisinos, 2005.

. Teoria da midiatização: uma perspectiva semioantropológica e

algumas de suas consequências. Matrizes. São Paulo, n. 1, p. 13-19, 2014. 